\title{
9. CLINICAL EVALUATION OF SHIVA GUGGULU AND SIMHNAD GUGGULU IN THE MANAGEMENT OF AMAVATA
}

\author{
Ingole Rajesh ${ }^{1 *}$, Suryawanshi Renuka ${ }^{2}$, Pawale Santosh ${ }^{3}$ \\ ${ }^{1 *}$ M.D. (Ayu.); Ph.D., (Ayu.); Asso. Professor, Post Graduate Department of Rasashastra\& B.K. , \\ YAMC \& RC, Kodoli, Kolhapur, Maharashtra \\ ${ }^{2}$ M.D. (Ayu.) ,Lecturer, GES's Ayurved Mahavidyalaya,Kolhapur. Maharashtra \\ ${ }^{3}$ M.D.(Ayu.);Scholar, Post Graduate Department of Rasashastra ,YAMC\& RC, Kodoli, Kolhapur, \\ Maharashtra.
}

Key words: - Shiva Guggulu, Simhnad Guggulu,Amavata, Sandhi Shula, Sandhi Shotha.

\section{INTRODUCTION:-}

Amavata is one of the dreadful disorders and included under the vata vyadhis in Ayurveda. The annual incidence rate of rheumatoid arthritis is low however the prevalence rate of the same is very high. Of all the rheumatic disorders, rheumatoid arthritis still remains a formidable disease, as it causes severe crippling deformities and functional disabilities. The disease can undergo spontaneous remission and it is difficult to forecast the outcome of the disease and it makes the evaluation of new drug is also difficult. If proper attention has not been paid the condition turns to its worse.

The severe pain and crippling deformities with functional abnormalities makes the patient to seek doctor's advice. Even in modern system of medicine the drug therapy for rheumatoid arthritis is empirical and is focused on 3 issues-

1. Relieving the pain along with control of inflammation,

2. Improving and maintaining the function and

3. Prevention of the deformity.

However none of the medicine available at present can give everlasting benefit thereby permanent remission from the symptoms. The drugs which are available as on today are only of value in achieving the symptomatic relief. But their use is restricted because of number of adverse effects attached to their usage. It is because of this reason the people are looking towards a safe and effective drug.

\section{OBJECTIVES OF THE STUDY:-}

1] To assess the comparative efficacy of Shiva Guggulu and Simhnad Guggulu in the management of amavata.

2] To find out a safe, simple, effective and economical method of treating Amavata.

3] To rule out possible adverse effect of study drugs.

\section{MATERIALS AND METHODS:-}

The therapeutic protocol in the present study includes 30 patients in 2 groups; selected from OPD/IPD of NIA Hospital Jaipur, fulfilling the criteria of diagnosis, with irrespective of their age, sex, religion etc, using randomized single blind method of trial.

- Inclusion criteria:-

$\checkmark \quad$ Patients having the signs and symptoms of Amavata.

$\checkmark \quad$ Patients with RA factor negative but having the symptoms of Amavata.

- Exclusion Criteria:

$\checkmark \quad$ Patients with complications of RA.

$\checkmark \quad$ Patients in late stage of RA.

- Criteria for Diagnosis:

A special proforma was prepared incorporating all the signs and symptoms based on both Ayurvedic as well as Modern descriptions. All the points in the perspective of Dosha, Dusya, Srotasa and Agni on Ayurvedic line were also included in the proforma. A detailed clinical history was taken initially and complete physical examination of 
each patient was carried out on the basis of proforma. RA factor test, $\mathrm{Hb} \%$, ESR, CBC

Table 1 Showing posology of trial drug : were carried out in all the patients.

- Posology:

\begin{tabular}{|c|c|c|c|c|c|}
\hline Group & Drug Administered & Dose & Anupana & $\begin{array}{c}\text { Time of } \\
\text { administration }\end{array}$ & $\begin{array}{c}\text { Duration of } \\
\text { treatment }\end{array}$ \\
\hline A & $\begin{array}{c}\text { Self made Shiva } \\
\text { Guggulu vati (R.S.S.) }\end{array}$ & $3 \mathrm{gm}$ & $\begin{array}{c}\text { Luke warm } \\
\text { water }\end{array}$ & $\begin{array}{c}\text { After meal twice } \\
\text { a day }\end{array}$ & 21 days \\
\hline B & $\begin{array}{c}\text { Self made Simhnad } \\
\text { Guggulu (V.S.) }\end{array}$ & $3 \mathrm{gm}$ & $\begin{array}{c}\text { Luke Warm } \\
\text { water }\end{array}$ & $\begin{array}{c}\text { After meal twice a } \\
\text { day }\end{array}$ & 21 days \\
\hline
\end{tabular}

R.S.S.- Rasendra Sara Samghraha Ref.

\section{V.S. - vangasena Samhita}

\section{- Follow up study:}

During the trial all patients were regularly analyzed and advised to attend O.P.D. after every 10 days

\section{Clinical Assessment:}

Assessment of the treatment was done on the basis of the relief in the clinical signs and symptoms of the disease. Most of the signs and symptoms of the disease described in Ayurvedic classics are subjective in nature. Hence in order to provide some objectivity to the subjective results and to make easy the statistical analysis, multidimensional scoring system was adopted for the patients. This symptoms score was calculated before and after the treatment through statistical analysis and percentage of relief was noted to assess the efficacy of therapy. Scoring pattern was adopted to assess the relief in the cardinal symptoms.

\section{- Criteria for Assessment of overall effect of therapy}

Data obtained from the parameters of assessment, before \& after the therapy was utilized to evaluate the overall effect of therapy.

- Marked improvement

$75 \%$ to $100 \%$ relief
- Moderate improvement

to $75 \%$ relief

- Mild improvement

to $50 \%$ relief

- No improvement

$25 \%$ relief

\section{$2 \quad$ Statistical Analysis}

The information collected on the basis of observation were analyzed by paired " $\mathrm{t}$ " test to evaluate the significances at different levels i.e. at $0.05,0.01$ and 0.001 levels. The obtained results were interpreted as follows,

$$
\begin{array}{lc}
\text { Not significant } \quad- & \mathrm{p}>0.10 \\
\text { Significant } & \mathrm{p}<0.05 \\
\text { Moderately Significant } & -\mathrm{p}<0.01 \\
\text { Highly Significant - } & \mathrm{p}<0.001
\end{array}
$$

\section{RESULTS:-}

After completion of the therapy of ShivaGuggul for 21 days, its effect on the clinical features were observed as presented by table 2. Its provide highly significant relief in Sandhi shotha(77\%), Sandhi Shula (68\%) ,Gaurava (60\%) and Aangmardh(45\%) [p<0.001], Effect was stastically significant in A-P Vedana(71\%) ,Sandhi Graha(45\%),Aruchi(45\%) and Jwara(100\%) [p<0.05]. 


\section{Ayurlog: National Journal of Research in Ayurved Science}

A Web based quarterly online published peer reviewed National E-journal of Ayurveda.

http://www.ayurlog.com

Vol. 01 Issue $1^{\text {st }}$ January- 2013

ISSN 2320-7329

After completion of the therapy of Simhnad Guggul for 21 days, its effect on the clinical features was observed as presented by table 3 . Its provide highly significant relief in Sandhi
Graha(92\%), Aangmarda (62\%),Aruchi (57\%) ,Sandhi Shotha (54\%) and Sandhi Shula (52\%) [p<0.001], Effect was stastically significant in A-P Vedana (83\%), and Jwara $(77 \%)[\mathrm{p}<0.05]$

Table 2 showing effect of the Group A (Shiva Guggulu) on various subjective parameters of Amavata

\begin{tabular}{|c|c|c|c|c|c|c|c|c|c|}
\hline \multirow[t]{2}{*}{ Symptoms } & \multirow[t]{2}{*}{$\mathbf{N}$} & \multicolumn{2}{|c|}{ Mean } & \multirow[t]{2}{*}{ Difference } & \multirow{2}{*}{$\begin{array}{l}\% \text { of } \\
\text { Relief }\end{array}$} & \multirow[t]{2}{*}{ S.D. } & \multirow[t]{2}{*}{ S.E. } & \multirow[t]{2}{*}{ ' $\mathbf{t}$ ' } & \multirow[t]{2}{*}{$\mathbf{P}$} \\
\hline & & BT & $\mathbf{A T}$ & & & & & & \\
\hline Sandhi Shula & 13 & 1.92 & 0.61 & 1.30 & 68 & 0.48 & 0.13 & 9.8 & $<0.001 \mathrm{HS}$ \\
\hline Sandhi Shotha & 13 & 0.69 & 0.15 & 0.53 & 77 & 0.51 & 0.14 & 3.7 & $<0.001 \mathrm{HS}$ \\
\hline Sandhi Graha & 13 & 0.84 & 0.46 & 0.38 & 45 & 0.50 & 0.14 & 2.7 & $<0.05 \mathrm{~S}$ \\
\hline A-P Vedana & 13 & 0.53 & 0.15 & 0.38 & 71 & 0.50 & 0.14 & 2.7 & $<0.05 \mathrm{~S}$ \\
\hline Aangmarda & 13 & 1.53 & 0.84 & 0.69 & 45 & 0.48 & 0.13 & 5.19 & $<0.001 \mathrm{HS}$ \\
\hline Aruchi & 13 & 0.84 & 0.46 & 0.38 & 45 & 0.50 & 0.14 & 2.73 & $<0.05 \mathrm{~S}$ \\
\hline Trishna & 13 & 0.07 & $\mathbf{0}$ & 0.07 & 100 & 0.27 & 0.07 & 1 & $>0.10 \mathrm{NS}$ \\
\hline Gaurava & 13 & 1.53 & 0.61 & 0.92 & 60 & 0.64 & 0.17 & 5.1 & $<0.001 \mathrm{HS}$ \\
\hline Jwara & 13 & 0.38 & $\mathbf{0}$ & 0.38 & 100 & 0.50 & 0.14 & 2.73 & $<0.05 \mathrm{~S}$ \\
\hline
\end{tabular}

Table 3 showings effect of Group B (Simhnad Guggulu) on various subjective parameters of Amavata:

\begin{tabular}{|c|c|c|c|c|c|c|c|c|c|}
\hline \multirow[t]{2}{*}{ Symptoms } & \multirow[t]{2}{*}{$\mathbf{N}$} & \multicolumn{2}{|c|}{ Mean } & \multirow[t]{2}{*}{ Difference } & \multirow{2}{*}{$\begin{array}{l}\% \text { of } \\
\text { Relief }\end{array}$} & \multirow[t]{2}{*}{ S.D. } & \multirow[t]{2}{*}{ S.E. } & \multirow[t]{2}{*}{ ' $\mathbf{t}$ ' } & \multirow[t]{2}{*}{$\mathbf{P}$} \\
\hline & & BT & $\mathbf{A T}$ & & & & & & \\
\hline Sandhi Shula & 15 & 2.5 & 1.2 & $\mathbf{1 . 3 3}$ & 52 & 0.48 & 0.12 & 10 & $<0.001 \mathrm{HS}$ \\
\hline Sandhi Shotha & 15 & 0.73 & 0.33 & 0.4 & 54 & 0.50 & 0.13 & 3 & $<0.001 \mathrm{HS}$ \\
\hline Sandhi Graha & 15 & 0.93 & 0.06 & 0.86 & 92 & 0.35 & 0.09 & 9.5 & $<0.001 \mathrm{HS}$ \\
\hline A-P Vedana & 15 & 0.4 & 0.06 & 0.33 & 83 & 0.48 & 0.12 & 2.64 & $<0.05 \mathrm{~S}$ \\
\hline Aangmarda & 15 & 1.8 & 0.66 & 1.13 & 62 & 0.51 & 0.13 & 8.5 & $<0.001 \mathrm{HS}$ \\
\hline Aruchi & 15 & 1.26 & 0.53 & 0.73 & 57 & 0.70 & 0.18 & 4 & $<0.001 \mathrm{HS}$ \\
\hline Trishna & 15 & 0.13 & $\mathbf{0}$ & 0.13 & 100 & 0.35 & 0.09 & 1.4 & $>0.10 \mathrm{NS}$ \\
\hline Gaurava & 15 & 0.73 & 0.4 & 0.33 & 45 & 0.72 & 0.18 & 1.7 & $>0.1 \mathrm{NS}$ \\
\hline Jwara & 15 & 0.6 & 0.13 & 0.46 & 77 & 0.83 & 0.21 & 2.16 & $<0.05 \mathrm{~S}$ \\
\hline
\end{tabular}




\section{Ayurlog: National Journal of Research in Ayurved Science \\ A Web based quarterly online published peer reviewed National E-journal of Ayurveda.}

\section{DISCUSSION:-}

As the present disease is born out from the vitiated vata and kapha. Main pathology in the disease is Ama nirmiti. As the trial drug (Shiva Guggulu and Simhnad Guggulu) had definite action on vitiated vata and kapha dosha. Most of the drugs used in this formulation were Katu, Tikta in Rasa and Ushna Virya which possess the antagonistic properties to that of Àma and Kapha which are the chief causative factors in this disease. Due to this Katu rasa and Ushna Virya leads to increase digestive power which also digests Àmarasa. Because of Tikshna, Ushna and Ruksha Guna pacify the vitiated Vata and Kapha and do not allow the Àma to stay at the site of pathogenesis and to create Srotorodha. .

Most of the drugs in the Shiva Guggul are Agnideepaka, pachana,Amanashana, Yogvahi and Vatanulomana property. Tikta Rasa remove adhered Dosha from the Dushita Srotas . Due to Srotovivronoti, Agnideepana and Pachana property of Katu Rasa helps in Strotashodhana.

Group A(Shiva Guggulu): - this group provides highly significant result in Sandhishula, Sandhi shotha, and Angamarda symptoms while Sandhi graha, A-P Vedana, aruchi and Jwara shows significant results. Trishna symptom shows non significant result, as this symptom was found only in 2 patients during trial.

Group B(Simhnad Guggulu): - This group gives highly significant relief in Sandhi shula, Sandhi shotha, Sandhi graha, Angamarda and Aruchi. A-P Vedana and Jwara provide significant relief while Trishna and Gaurava provide non significant result.

From above data it can be analysed that Group A provide highly significant relief in Sandhi shula and Sandhi shotha as compare to Group B while Group B provide highly significant relief in Sandhi graha as that of Group A. both the Groups gives non significant result in Trishna.

In assessing overall effect of therapy it was seen that -

In Group A (Shiva Guggulu) 13 patients were treated, out of which, $6(46.15 \%)$ patients got marked improvement, $5(38.47 \%)$ patients got cured and 2 patients (15.38) got mild improvement.

In GroupB (Simhnad Guggulu) -out of 15 patients, 6 patients $(40 \%)$ got marked improvement, 5 patients $(33.33 \%)$ got improved and 4 patients $(26.67 \%)$ were cured.

$\checkmark \quad$ None of the patient was found unchanged in both the groups.

$\checkmark \quad$ The improvement was statistically highly significant in both the groups but

comparatively better results were observed in group-B (table 5.42), it may be because of comparatively high percentage of Guggulu and Eranda oil in Simhnad Guggulu which helps to relieve the shool, shotha and sandhi graha. Guggulu is well known anti inflammatory and analgesic drug, also in Ayurvedic classic it's Rasayana property was mentioned which helps to overcome the immunological derangement induced in RA by boosting once immunity which breakes the pathogenesis of the disease.

\section{CONCLUSION:-}

1. Both the trial drugs are effective in the management of Amavata but Simhnad Guggulu is more effective than Shiva Guggulu. 2. This preparation did not impart any side effect and the given dose was well tolerated by the patient without any undesirable side effect like Nausea, Vomiting etc.

\section{References and bibliography:}

1. Basic Pathology, W.B. Saunders International Edition, Stanley L. Robbins, Vinay Kumar, Ramzi Cotran. $5^{\text {th }}$ Edition 1992

2. Davidson's principles and practice of Medicine, edited by Edwards, $17^{\text {th }}$ edition, 1995.

3. Kaya Chikitsa, $2^{\text {nd }}$ part, by Prof. Ajay Kumar Sharma, Chaukhambha Orientalia, Delhi, Edition: 2010. 
Ayurlog: National Journal of Research in Ayurved Science

A Web based quarterly online published peer reviewed National E-journal of Ayurveda.

4. Madhava Nidana with Madhukosha commentary edited by Shri Sudarshan Shastri \& Shri Yadunandan Upadhyaya, Chaukhambha Sanskrit Samsthana,26 ${ }^{\text {th }}$ edition, 1976.

5. Rasa Tantra Sara Va Siddha Prayoga Samgraha published by Krishna Gopala Ayurveda Bhawan, $16^{\text {th }}$ Edition 2003..

6. Rasendra Sara Samgraha of Gopal Krishna Bhatta with Rasayani hindi commentary by Pt. Neelkanth Mishra edited by Ramtej Pandey, Chaukhamba Sanskrit Prathisthan, Delhi, Reprint 2000.

7. Text Book of Pathology by Harsh Mohan, Jaypee Brothers Medical Publishers (P) Ltd New Delhi, $3^{\text {rd }}$ Edition 1998.

8. Vangasen Samhita of Vangasen with hindi translation by Kavivar Shri Shaligramji Vaishya edited by Sri Vaidya Srikrishnadas Prakasan Mumbai, Edition 1996. 